\title{
Research on Vegetation Cover Change Detection of the North-South Mountains in Lanzhou City
}

\author{
Quanfu Niu*, Yingxue Zhang, Junmei Kang and Xiuxia Zhang \\ School of civil engineering \\ Lanzhou University of Technology \\ Lanzhou 730020, China \\ *Corresponding author
}

\begin{abstract}
Based on three periods (year 2000, 2008 and 2013) Landsat images and basic geographic data of the region, the vegetation cover change detection of the north-south mountains in Lanzhou city was quantitatively analyzed and dynamically monitored with calculating of the normalized difference vegetation index (NDVI) and fractional vegetation cover (FVC). The conclusion was acquired and so as to provide technical support for the ecological constructions in this region.
\end{abstract}

Keywords- lanzhou city; vegetation cover; NDVI; FVC

\section{INTRODUCTION}

Lanzhou, located in hinterland of China inland, is the capital of Gansu province. As one of the most important large city in North-West. The feature is, its natural environment is poor because of the lack of rain. So every year, the local government invests a lot of money to plant trees in the north-south mountains of Lanzhou(FIGURE I). After many years of efforts, they have achieved very good result. Now, how to effectively evaluate the results and provide decision support for the management, that is one of our study themes.

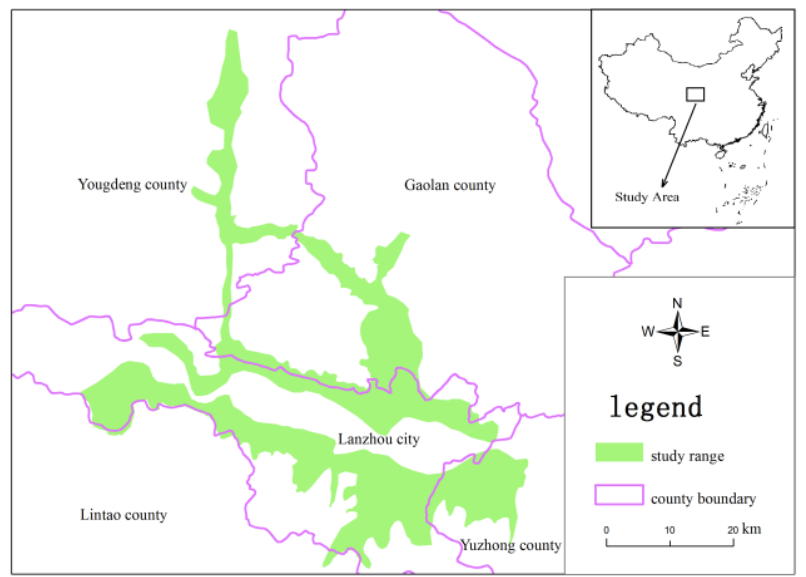

FIGURE I. STUDY AREA

Vegetation is the general terms of the plant community which covered on the surface of Earth. As it can analyze a regional eco-environment well, it has become one of the most important factors in environmental analysis. Vegetation index, which can calculate from remote sensing data, has become the key method to detect regional eco-environment[1-4]. At present, there are many methods to calculate vegetation index, such as: Ratio Vegetation Index (RVI), Difference Vegetation Index (DVI), and Normalized Difference Vegetation Index (NDVI), etc.. Especially, NDVI has already become the most general method because of analyzing the regional vegetation well. So this study was mainly to dynamically monitored vegetation changes of the north-south mountains in Lanzhou by means of calculating NDVI and Fractional Vegetation Cover(FVC) based on three periods(year of 2000,2008 and 2013) data of Landsat images, It hopes to provide technical support for the ecological constructions in this region.

\section{DATA AND METHODS}

\section{A. Research Data}

The main research data are Landsat images. Its orbit number is 131035, which acquired from the USGS web(www.glovis.usgs.gov) and photographed respectively in July 15, 2000, July 28, 2008 and August 8, 2013. It are nice growth periods for the artificial and natural vegetation and as typical seasons for dynamically monitor the vegetation coverage changes of the north-south mountains. The auxiliary data includes: digital elevation model (DEM) and basic geographic data, etc.

\section{B. Research Methods}

The technology program of this study was as follows (FIGURE II) :

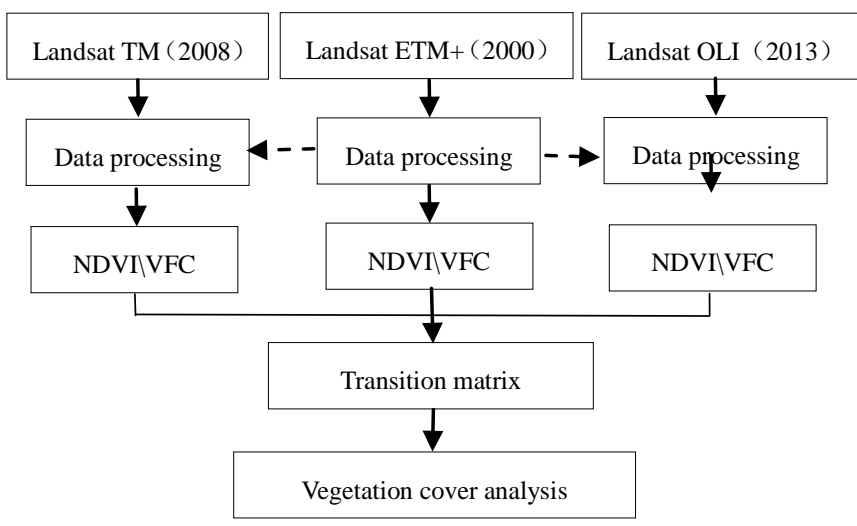

FIGURE II. TECHNOLOGY PROGRAM 
Data preprocessing mainly includes: images enhancement, bands combination, geometric correction, images cropping and so on. The geometry correction respectively matched the image of 2008 and 2013 with the reference image of 2000 . The matching precision was controlled in less than one pixel.

\section{REMOte SENSING ESTIMATION FOR VEGETATION COVER}

\section{A. The Calculation of NDVI}

Experiments have shown that plant leaves in the visible red band has a strong absorption and in the near infrared has a strong reflection, which is the physical basis of remote sensing of vegetation. Therefore, different vegetation indices can be obtained by different combinations of these two bands. The vegetation index NDVI was first suggested and has been widely used in different ways. It reflects the changes of green biomass, chlorophyll content and canopy water potential. The Calculation formula for NDVI is as follows:

$$
N D V I=\frac{D N_{N I R}-D N_{R}}{D N_{N I R}+D N_{R}}
$$

Where, $D N_{I R}, D N_{R}$ are respectively expressed the radiation values which were measured in near-infrared and infrared band by the sensor. The differences of NDVI value calculated with different-time-phase remote sensing image can response the vegetation cover changes of a region very well.

According to the formula (1), the NDVI values were calculated with Landsat images of the year 2000, 2008 and 2013. And then the NDVI figures of the research region were acquired with envi5.1 software(FIGURE III). The results show that the NDVI value is between -1 and 1 , among which: NDVI values of cloud, water and snow are negative (less than 0); NDVI values of rock and bare soil are close to 0; NDVI value of the vegetation cover region is positive (greater than 0). Furthermore, the better the vegetation cover, the greater the NDVI value .
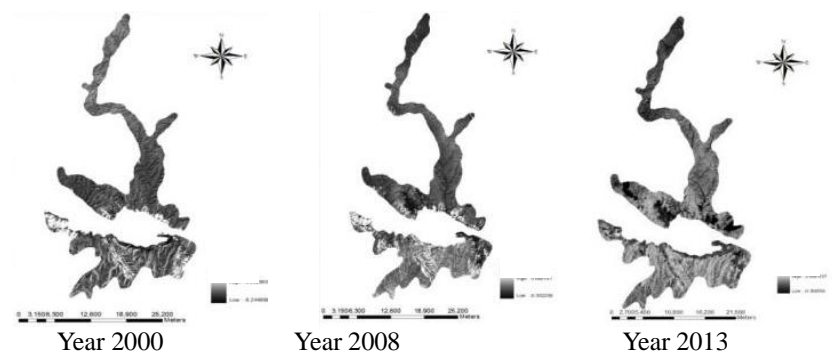

FIGURE III. NDVI OF THE SOUTH-NORTH MOUNTAINS

\section{B. The Calculation of FVC}

FVC is refers to the percentage of vegetation cover(including leaves, stems and branches) on the ground of vertical projection area of the total statistical area. It is often used to study changes in vegetation, eco-environment, water conservation, climate, etc. At present, there are several FVC calculation methods using remote sensing. A more practical approach is to use NDVI to approximately estimate the value of FVC. The simplified calculation formula for FVC is:

$$
F V C=\frac{N D V I-N D V I_{\min }}{N D V I_{\max }-N D V I_{\min }} \times 255
$$

Where, $N D V I_{\text {min }}$ is the minimum value of the regional NDVI, while $N D V I_{\max }$ is the maximum value of the regional NDVI. In order to show the relationship between FVC and pixel gray value, the VFC value would stretch to $0-255$.

With the formula (2), the FVC maps of the study region were calculated and classified into five types(TABLE I, FIGURE IV). And then, Statistical calculation for the FVC area of different class gained from the three period remote sensing images in 2000, 2008, and 2013(TABLE II).

TABLE I. VEGETATION COVER TYPES AND PIXEL GRAY VALUE

\begin{tabular}{ccc}
\hline Types & Pixel gray value & Vegetation cover grade \\
\hline Class 1 & $0 \sim 128$ & inferior grade \\
Class 2 & $129 \sim 138$ & poor grade \\
Class 3 & $139 \sim 155$ & middle grade \\
Class 5 & $156 \sim 190$ & good grade \\
\hline & $191 \sim 255$ & superior grade \\
\hline & &
\end{tabular}

FIGURE IV. FVC OF THE SOUTH-NORTH MOUNTAINS

TABLE II. EACH CLASS OF FVC AREA AND PERCENTAGE

\begin{tabular}{ccccccc}
\hline \multirow{2}{*}{ Types } & \multicolumn{2}{c}{ Year 2000 } & \multicolumn{2}{c}{ Year 2008 } & \multicolumn{2}{c}{ Year 2013} \\
\cline { 2 - 7 } & $\begin{array}{c}\text { Area } \\
(\mathrm{km} 2)\end{array}$ & $\begin{array}{c}\text { Percentage } \\
(\%)\end{array}$ & $\begin{array}{c}\text { Area } \\
(\mathrm{km} 2)\end{array}$ & $\begin{array}{c}\text { Percentage } \\
(\%)\end{array}$ & $\begin{array}{c}\text { Area } \\
(\mathrm{km} 2)\end{array}$ & $\begin{array}{c}\text { Percentage } \\
(\%)\end{array}$ \\
\hline Class1 & 393.07 & 94.57 & 195.74 & 47.10 & 0.12 & 0.05 \\
Class2 & 6.56 & 1.58 & 96.14 & 23.12 & 0.11 & 0.06 \\
Class3 & 6.30 & 1.51 & 75.12 & 18.08 & 1.34 & 0.36 \\
Class4 & 7.81 & 1.88 & 38.59 & 9.28 & 54.79 & 13.18 \\
Class5 & 1.88 & 0.46 & 10.03 & 2.42 & 358.88 & 86.35 \\
\hline
\end{tabular}

FIGURE IV and TABLE II showed that the area of vegetation cover has had a larger changes form year 2000 to 2013. On the whole, it presented a growing trend. In which, 
the class 1 area of vegetation cover changed in the largest. Its area of year 2000 was reduced from $393.07 \mathrm{~km} 2$ to $0.12 \mathrm{~km} 2$ in year 2013, and most of it were transferred to other class. From year 2000 to 2008, the class2 area was grown but reduced from year 2008 to 2013. For class 3 and class4, the changes of their area weren't obvious. But the class5 was changed significantly. Especially in the five years among year 2008 to 2013, its area percentage was growing from $2.42 \%$ to $86.35 \%$. It showed that the vegetation cover during 2008-2013 was better than during 2000-2008 and the vegetation growth was getting better.

\section{Analysis of Vegetation Cover Dynamic Changes}

In order to quantitatively analyze the changes of vegetation cover from year 2000 to 2013, Tabulate Area Tool of ArcGIS were used to calculate each type's changes of the vegetation cover in 2000, 2008 and 2013, and then the transfer matrix of each type's vegetation cover area of year 2000-2008 and 2008-2013 were obtained to quantitatively analyzed the transfer of the types each other(TABLE III-VI).

TABLE III. AREA'S TRANSFER MATRIX IN 2000-2008

\begin{tabular}{cccccc}
\hline Types & $\begin{array}{c}\text { Class } \\
1\end{array}$ & Class2 & Class3 & Class4 & Class5 \\
\hline Class1 & 188.6 & 93.34 & 71.21 & 32.61 & 7.31 \\
Class2 & 1.99 & 1.02 & 1.53 & 1.39 & 0.63 \\
Class3 & 1.69 & 0.79 & 1.14 & 1.87 & 0.81 \\
Class4 & 2.68 & 0.80 & 1.06 & 2.17 & 1.1 \\
Class5 & 0.78 & 0.19 & 0.18 & 0.55 & 0.18 \\
\hline
\end{tabular}

TABLE IV. SWITCHING IN AND OUT IN 2000-2008

\begin{tabular}{lccccc}
\hline \multicolumn{1}{c}{ Types } & Class1 & Class2 & Class3 & Class4 & Class5 \\
\hline $\begin{array}{l}\text { switching-i } \\
\text { n (km2) }\end{array}$ & 7.14 & 95.12 & 73.98 & 36.42 & 9.85 \\
$\begin{array}{l}\text { switching-o } \\
\text { ut (km2) }\end{array}$ & 204.47 & 5.54 & 5.16 & 5.64 & 2.48 \\
\hline
\end{tabular}

TABLE V. AREA'S TRANSFER MATRIX IN 2008-2013

\begin{tabular}{cccccc}
\hline Types & Class1 & Class2 & Class3 & Class4 & Class5 \\
\hline Class1 & 0.06 & 0.06 & 1.02 & 35.59 & 159.12 \\
Class2 & 0.02 & 0 & 0.18 & 8.70 & 86.61 \\
Class3 & 0.01 & 0.02 & 0.06 & 5.23 & 70.13 \\
Class4 & 0.02 & 0.02 & 0.05 & 3.73 & 34.7 \\
Class5 & 0.01 & 0.01 & 0.03 & 1.54 & 8.32 \\
\hline
\end{tabular}

TABLE VI. SWITCHING IN AND OUT IN 2008-2013

\begin{tabular}{cccccc}
\hline Types & Class1 & Class2 & Class3 & Class4 & Class5 \\
\hline $\begin{array}{c}\text { switching-in } \\
(\mathrm{km} 2)\end{array}$ & 195.79 & 95.51 & 75.39 & 34.79 & 1.59 \\
$\begin{array}{c}\text { switching-out } \\
(\mathrm{km} 2)\end{array}$ & 0.06 & 0.11 & 1.28 & 51.06 & 350.56 \\
\hline
\end{tabular}

Table III-VI show: In 2000-2008, the class1 of vegetation cover was mainly switched to class2, about $93.34 \mathrm{~km} 2$. Second to class3. A little was switched to class4 and class5, about $7.31 \mathrm{~km} 2$. Furthermore, to class1, the area of switching-out was $204.47 \mathrm{~km} 2$ and switching-in was $7.14 \mathrm{~km} 2$. To class 2 , the area of switching-out was $95.12 \mathrm{~km} 2$ and switching-in was $5.54 \mathrm{~km} 2$. The result showed that the switching-out of vegetation cover was more than switching-in and the vegetation cover was a growth trend. But class4 and class5 were changed little. So, in 2000-2008, the vegetation cover was mainly low and moderate among 8 years.

In 2008-2013, the vegetation at all classed were switched to the next class. And much more were switched to class5. From table VI, to class4 and class5, the area of switching-in were more than switching-out and in contrast to other classes. It showed that the vegetation cover in 2008-2013 were growing well.

\section{CONCLUSIONS}

This study was mainly to dynamically monitored vegetation changes of the north-south mountains in Lanzhou city by means of calculating NDVI and FVC based on three periods(year 2000,2008 and 2013) data of Landsat images. And by counting area of all types of FVC and analyzing the transition matrix, this study reached conclusions as follows:

a) During the period 2000-2013, in general, the vegetation cover of the north-south mountains in Lanzhou city was in a growing trend. The area of inferior class (class1) were changed maximally. For example, the area was from $393.07 \mathrm{~km} 2$ in 2000 to $0.12 \mathrm{~km} 2$ in 2013 ; The area of medium class vegetation cover(class 3 ) have a small changes in 2000-2008 and a bigger changes in 2008-2013; Especially the area of good and superior class have a large changes from 2000-2013.

b) The analysis of two phases of transfer matrix of 2000-2008 and 2008-2013 indicated that the vegetation cover area of class1 were transferred maximally. And the vegetation cover area of class 5 have a small change in 2000-2008 and a bigger change in 2008-2013.

c) This study shows that by 2013 , the vegetation cover in the region has entered a good growing period, and the afforest effect of the mountains were outstanding. The conclusions of this study was proofed by a on-site inspection. It mainly reflected in two aspects: Firstly, the government-led policies and vigorously promote investment were the root cause. Secondly, the local people's awareness of green was continuously improved, especially some ecological protection and recovery works done by the local government have played an important role in the afforest of the north-south two mountains and vegetation restoration.

\section{ACKNOWLEDGMENT}

This research is supported by the National Natural Science Foundation of China (41461084), the Natural Science Foundation of Gansu province (145RJZA180) and Alumni Foundation of Civil Engineering 77, Lanzhou University of Technology(TM-TJ-1402). 


\section{REFERENCES}

[1] ZHANG Qing-yu, ZHAO Dong-sheng, WU Shao-hong, DAI Er-fu, Research on Vegetation Changes and Influence Factors Based onEco-geographical Regions of Inner Mongolia, SCIENTIA GEOGRAPHICA SINICA,2013,33(5):594-601.

[2] Tucker C J.Red and photographic infrared linear combination for monitoring vegetation[J]. Remote Sensing of Environment, 1979, (8):127-150.

[3] Beck P S A,Atzberger C,Høgda K A.Improved monitoring of vegetation dynamics at very high latitudes, a new method using MODIS NDVI[J].Remote Sensing of Environment, 2006, 100(3):321-336.

[4] Xin Z B,Xu J X,Zheng W.Spatiotemporal variations of vegeta-tion cover on the Chinese Loess Plateau (1981-2006): Impacts of climate changes and human activities[J].Science in China Se-ries D:Earth Sciences, 2008,51(1):67-78. 